\title{
ROBERT ERVIN HOWARD'S VISION OF THE SUPERNATURAL IN BEYOND THE BLACK RIVER
}

\author{
Piotr GulanOWSKI \\ piotr.gulanowski@gmail.com \\ Wyższa Szkoła Filologiczna we Wrocławiu \\ Poland
}

\begin{abstract}
The plot and the presented world of Robert Ervin Howard's Beyond the Black River are representative of sword and sorcery, a subgenre of fantasy fiction that Howard is claimed to have pioneered. It has been proposed that the worlds in fantasy fiction are coherently organised, natural, and material. Nevertheless, supernatural elements that are not consistent with the structure of the universe are present. The struggle between the structured worlds and the chaotic supernatural that is resolved by an intervention of a barbarian hero constitute the essence of the sword and sorcery subgenre. These elements can also be found in Beyond the Black River by Howard, who employs contrastive images to present the supernatural.

Key words: Robert Ervin Howard, Beyond the Black River, fantasy fiction, the fantastic, the supernatural, sword and sorcery, Conan

The paper presents a close analysis of the world of R.E. Howard's Beyond the Black River and its relation to the worlds of other works of the sword and sorcery subgenre of fantasy literature. In the paper it is argued that the combination of an organised, coherent, material world and the chaotic and menacing supernatural world is an integral, defining element of sword and sorcery literature. It is proposed that this combination is also inherent to the world of Beyond the Black River. The paper presents the contrastive imagery that Howard uses to signify the supernatural. The images are analysed in close connection with the linear structure of the plot. It is proposed that such linear way of presenting the images is aimed at creating the effect of mystery through a gradual revealing of the supernatural nature of certain characters and creatures appearing in Beyond the Black River. The problems of the changing definition of the notions of fantasy and the fantastic in literary criticism are discussed, as well. The aim of the present paper is also to show that the world of Howard's Beyond the Black River, the role of the barbarian Conan within it, and the structure of the plot revealing the nature of the world are not only characteristic of sword and sorcery, but also defining for this subgenre.

Robert Ervin Howard was an American writer who gained wide recognition as the creator of Conan of Cimmeria, a fantasy fiction character described as "the paradigm example of the ultramasculine barbarian whose reserves of strength, courage, and sheer willpower are adequate to any situation, including assaults by sorcerous magic" (Stableford, 2005, p. 206). He was also prolific in a number of genres, including sea adventure, Western, and boxing stories as well as sword and sorcery/heroic
\end{abstract}


fantasy. During his lifetime Howard's prose was printed in pulp fiction magazines, such as Weird Tales. The unorganised work, which had been left after the author's suicide in 1936, was edited by Lyon Sprague De Camp and published in a number of short story collections. D'Ammassa states that "with the exception of J.R.R. Tolkien, it is unlikely that any 20th-century fantasy writer rivalled the influence of Robert E. Howard on his fellow writers" (2006, p. 168). Howard is often credited as the pioneer of sword and sorcery (D'Ammassa, 2006; Stableford, 2005), a genre also termed heroic fantasy. According to Hinckley, "Howard's original fusion of naturalistic and supernatural mythic themes in the Conan stories played the definitive role in establishing a popular subgenre of heroic fantasy" (2002, p. 108), which has gained immense popularity among readers and has influenced other fantasy fiction writers. The figure of Conan has also become a source of inspiration for Hollywood filmmakers, with Conan the Barbarian and Conan the Destroyer (both starring Arnold Schwarzenegger as the main character and released in 1982 and 1984 respectively), and with yet another film under the title Conan the Barbarian screened in 2011. Although the character only appears in sixteen stories and one novel by Robert E. Howard, all of them published between 1932 and 1936, Conan became the prototype of a sword and sorcery hero. It may be proposed that, as D'Ammassa claims, "Conan is the barbarian hero against which all others are measured and the single most dominant character in all of sword and sorcery fiction" (2006, p.63).

Conan is one of the central characters of Howard's Beyond the Black River. It can be proposed that, with its characters, plot, and presented world, the short story in question may serve as an illustration of the relationship between the natural and the supernatural in the sword and sorcery genre. Beyond the Black River, published first in Weird Tales in 1935, is a story of a settlement in the land of Conajohara, situated between the Thunder River and the titular Black River. As Howard indicates, the settlers from Aquilonia, a highly civilised empire, had driven the native people, the Picts, into the jungle beyond the Black River before they built a fort and numerous villages. It has been argued that "the Picts (...) are based in some ways on the stereotypes of Native Americans in western fiction »because « [they] live in thatch and mud huts, they travel the rivers by canoe, they lie in wait and ambush unsuspecting pioneers, (...) they move silently in the forest [and] armed with bows and arrows, they cause feathered shafts to sprout from woodmen's backs" (Shovlin, 2013, p. 93). With the peaceful and civilised ${ }^{1}$ settlers facing an immediate savage threat, and with Conan serving as a mercenary ranger with the garrison of the one and only fort protecting the villages from the Pictish warriors lurking in the jungle, Beyond the Black River can, in fact, be rendered as a frontier story. However, as the Picts are aided in their struggle against the Aquilonians by a wizard who has the ability to use sources of magic and wisdom of ancient worlds beyond to summon demons and legendary beasts, this seemingly realistic portrayal of the world of the settlers and savages is confronted with the supernatural. The present paper argues that such structure of the plot and the presented world is not only typical of Robert E. Howard's Conan stories, but of the entire sword and sorcery subgenre of fantasy fiction, as well.

That is, as the author of the story clearly suggests, weak and helpless in the face of an organised violent assault. 


\section{FANTASY, THE FANTASTIC, AND THE SUPERNATURAL}

In relation to the origins and the defining characteristics of fantasy fiction it has been stated that "although it is the most recent genre of literature to acquire a marketing label, it is also the most ancient genre that is readily identifiable" (Stableford, 2005, p. 36). This apparently paradoxical circumstance stems from the way the notion of the fantastic is popularly understood. According to Jackson, the Latin-derived meaning of the term is "that which is made visible, visionary, unreal ... all imaginary activity is fantastic, all literary works are fantasies" (1981, p. 13). Furthermore, Stableford proposes that "fantasy is the faculty by which simulacra of sensible objects can be reproduced in the mind: the process of imagination"(2005, p. 35) and underscores the pejorative connotations of the term which "comes ready-tainted with implications of unworthiness, of a failure of some alleged duty of the human mind to concentrate on the realities of existence" (2005, p. 35). This understanding as well as the negative emotional associations made in relation to fantasy and the fantastic are to be based in the historical perceptions of the realm of the imaginative, as "Geoffrey Chaucer, the first writer known to us who worked in a language recognizably akin to modern English, uses the word fantasye to refer to strange and bizarre notions that have no basis in everyday experience" which are regarded as "self-indulgent folly, whether [they are] a purely psychological phenomenon (a fanciful aspect of daydreaming) or a literary one" (Stableford, 2005, p. 36).

It is not only because of the apparent pejorative implications of the notion of the fantastic, but also due to the broad, general understanding of the term that render it useless in literary criticism. All worlds, characters, and plots presented in fiction are the fruit of the imagination of writers, regardless of whether their literary works are made to resemble reality or intended to depict entirely new universes. Furthermore, it has been proposed that the purely negative, Chaucerian approach to the fantastic was prevalent before 1969 (Stableford, 2005, p. 36). In this regard, the term fantasy literature would denote some futile exercise in childlike escapism aimed at severing readers' contact with the real world by allowing them to indulge in excursions into some nonsensical creations. However, with the undeniable presence of fantastic elements in Romantic and the later works of the Symbolists, with the appearance of the imaginative fiction of William Morris, George MacDonald, and Lord Dunsany, and with the subsequent emergence of the fantasy genre in the prose of J.R.R. Tolkien, R.E. Howard, and others, it was necessary to revise the critical approach to fantasy and the fantastic and to essentially redefine the notions themselves.

There are two major approaches in the above mentioned contemporary terminological revision. Stableford (2005) argues that no distinction should be made between the notions of the fantastic and fantasy, which leads to the claim that the origins of fantasy literature, i.e. the literature employing fantastic elements (defined as the supernatural, as opposed to the naturalistic), date back to Homer's Iliad and Odyssey. The critic, however, recognises fantasy fiction as a distinct and separate genre that emerged with the publication of J.R.R. Tolkien's works. In fact, he states that "Tolkien 
was [fantasy genre's] Homer" (Stableford, 2005, p. 45). An alternative proposition is that the notion of fantasy only be applied to fantasy fiction as a genre and a mode, with the unrealistic elements of literature predating the genre originated by Tolkien described as the fantastic. It is proposed that although the fantastic "now commonly comprises a variety of fictional works which use the supernatural or apparently supernatural ... not all works in which the supernatural or eerie appears are classified as fantastic" (Parkinson, 2006, p. 82); furthermore, a clear distinction is made between the fantastic and "works of fantasy, such as Tolkien's fiction and C. S. Lewis's Narnia series, [which] create their own coherently organized worlds and myths" (Parkinson 2006, p. 82). The coherence of presented worlds and narratives in fantasy fiction is emphasised by Clute (1997). He claims that whereas "much world literature has been described, at one time or another, as fantasy ... conceived as being in contrast to Realism," (Clute, 1997, p. 337) the essence of fantasy as a genre is, in fact, a certain specific structure: fantasy is defined as a self-coherent narrative that allows its readers to coinhabit the tale (Clute, 1997, p. 337). Therefore, the presented worlds of fantasy fiction are not random and chaotic collections of imaginary elements. On the contrary, they are consistent and governed by certain laws and regularities. Because the systematic structure of those universes resembles the real world and the characters inhabiting them have the qualities of real human beings, they are all vulnerable to intrusions of the chaotic and menacing supernatural.

The character of Conan and Howard's short stories, including Beyond the Black River, belong to, or, as Hinckley (2002) claims, have been the pioneers of, the sword and sorcery subgenre of fantasy fiction, in which the coherent structure of fantasy worlds and the intrusive supernatural are clearly manifested. According to Hinckley (2002) and Clute (1997) the term sword and sorcery was coined by Fritz Leiber, an American writer of horror and fantasy, in response to the emergence of a subgenre of fantasy fiction that combined adventures of muscular heroes inhabiting consistent presented worlds resembling the real one (often bringing to mind the Europe of Antiquity or the Middle Ages) with supernatural elements. As Hinckley proposes, in such works of fiction "the world is presented in terms of a struggle between great forces, (...) [those] of natural law and unnatural chaos" (Hinckley, 2002, p. 107). This conflict is often emphasised by the further clash between civilisation and barbarism, as "sword and sorcery assumes that the intimate connection of pre-technological peoples with their own mythic consciousness makes them susceptible to dark supernatural influences, yet also attunes them to their own heroic potential" (Hinckley, 2002, p. 107). The role of the uncivilized hero is of crucial importance to the plot as well as the structure of the world, because "[his] victories imply a larger order from which overcivilized (decadent) people have become estranged" (2002, p. 107). In consequence, stories in sword and sorcery fiction are essentially concerned with how the conflict between the civilised, the uncivilised, and the supernatural is resolved through the deeds of a barbaric, uncorrupted by inherently decadent civilisation hero. The hero is able to face the chaotic forces from beyond the world in which he and other characters dwell thanks to the contact that he has with the mythic and the supernatural. Such a structure is reflected in the plot and the world of R.E. Howard's Beyond the Black River. 
The events of the discussed short story take place in the Hyborian Age, which Hoffman calls "one of the most convincing projected realities in modern fiction" (2004, p. 5). The coherence of this world, with its geography, history, myths, beasts, and peoples, as well as the effort made to allow it to imitate the real one are emphasised by R.E. Howard in the introductory passage to his essay entitled The Hyborian Age:

When I began writing the Conan stories (...) I prepared this 'history' of his age and the peoples of that age, in order to lend him and his sagas a greater aspect of realness. And I found that by adhering to the 'facts' and spirit of that history, in writing the stories, it was easier to visualize (and therefore to present) him as a real flesh-and-blood character rather than a ready-made product. In writing about him and his adventures in the various kingdoms of his Age, I have never violated the 'facts' or spirit of the 'history' here set down, but have followed the lines of that history as closely as the writer of actual historical-fiction follows the lines of actual history (Howard, 1938, par. 1).

The above passage evidences that the wild land of Conajohara, the civilised, yet decadent Aquilonia, the dark forests beyond the Black River and the menacing, warrior Picts inhabiting them, and the brave, yet essentially weak settlers, as well the barbarian Conan and his deeds are created in such a way as to resemble if not actual historical persons and places, then at least the characters and settings of historical fiction. Nevertheless, the conflict between the Picts and the Aquilonians aided by Conan is not the only struggle in Beyond the Black River. The real danger is presented by the wizard of Gwawela, Zogar Sag, and the demon and beasts he summons out of the jungle by means of magical powers which only the uncivilised Conan with his barbaric knowledge of the mythical is able to face. That is why it can be stated that the conflict between the coherently structured, material presented world and the chaotic supernatural that constitutes the essence of the sword and sorcery fiction is present in R.E. Howard's short story.

\section{THE SUPERNATURAL: ITS IMAGE AND STRUCTURE}

One of the characters which play a key role in foregrounding the supernatural aspects of Beyond the Black River is Zogar Sag, a wizard residing in the village of Gwawela behind the Black River separating the jungle from the Aquilonian settlers, and apparently a Pictish native. The wizard is well-known to the soldiers in the fort, as well as to Conan himself. It is in the first chapter of Beyond the Black River that the readers learn of Zogar Sag's supernatural powers and how they are manifested in his attempts to overthrow the Aquilonian rule. However, it is only later on in the story that the actual nature and origins of the character are revealed. Since the structure of the short story is linear, the elements of the supernatural are unveiled consecutively. It may be thus proposed that such a structure is used in order to create the effect of a mystery. Because it may be assumed that it was Howard's intention to allow his readers to discover the increasingly terrifying features of the nature of the un-human, chaotic menace, its images shall be discussed in relation to the linear order of the presented events, as well. 
The first mention of Zogar Sag is made when Conan and Balthus, a newly arrived settler, encounter a form of a demonic being and the body of a merchant in the forest near the Aquilonian fort. The supernatural nature of the creature that Conan and Balthus are about to face is revealed before they even have a chance to see it: Balthus' ears are "outraged by the most frightful cry he had ever heard" (Howard 1935, Conan Loses His Ax, par. 39); a cry that is not human and sounds like "a demoniacal caterwauling of hideous triumph that [seems] to exult over fallen humanity and find echo in black gulfs beyond human ken" (Howard, 1935, Conan Loses His $A x$, par. 39). It is at this point that the first reference to the presence of a supernatural threat is made: the danger clearly comes from outside that which is human. Therefore, an opposition between the material, naturalistic, historical world inhabited, understood, and controlled by people and the menace of an entirely alien and chaotic nature is established. This opposition is prevalent throughout the story. The source of the un-human voice is identified by Conan as a forest devil, a being, as the barbarian claims, controlled by the wizard of Gwawela and sent from the swamps beyond the Black River to avenge the wizard's earlier capture by the soldiers of the fort. Having made an escape from his cell, Zogar Sag swears to have all the people responsible for his imprisonment killed. As it turns out, the wizard is successful: he manages to lure all the soldiers and a merchant into the forest and has them decapitated. Zogar Sag is, therefore, established as a being in control of the supernatural elements that threaten the order of the material world. He constitutes a living, active centre, as it were, of the supernatural in the story.

When Conan and Balthus examine the body of the merchant lying in the middle of a forest road, the un-human aspects of the creature responsible for the deaths of the wizard's enemies are once again suggested rather than openly revealed. The victim's throat is cut by what appears to be a talon, rather than a sword, a knife, or the claws of a panther. What is more, "under the bushes at the edge of the path" the characters find "a footprint, made in blood on the hard loam," a mark that makes Balthus' scalp prickle, as he believes that "neither man nor any beast that he had ever seen could have left that strange, monstrous, three-toed print, that was curiously combined of the bird and the reptile, yet a true type of neither." Conan suggests that the footprint was left by a swamp demon from "the swamps beyond the Black River" (Howard, 1935, Conan Loses His Ax, par. 62-64). The passage illustrates another aspect of the supernatural in the story: not only is it un-human, but also outside of the world of all living creatures, as its form cannot be associated with any animal. It is comprised of a chaotic combination of body parts and features of creatures belonging to the material and natural world of the Hyborian age; however, these elements are misplaced in a way that makes the unnatural character of the being manifest; at the same time, they evoke terror in the characters that belong to the human and the material universe. It is suggested that the demon is of a worldly origin; only later is it revealed that its nature is entirely otherworldly.

While the night falls in the forest and Conan and Balthus make their way to the fort, they hear a female cry for help from among the trees. As they try to follow it, "the sound [rings] out again - behind them, in the direction of the trail they had just 
quitted." The sound rises "piercingly and pitifully, the cry of a woman in frantic terror - and then, shockingly, it [changes] to a yell of mocking laughter that might have burst from the lips of a fiend of lower Hell" (Howard, 1935, Conan Loses His Ax, par. 80). The characters turn back towards the path, now perfectly aware that they are, in fact, following the demon. The following passage describes what they see:

Something was moving through the deep bushes that fringed the trail - something that neither walked nor flew, but seemed to glide like a serpent. But it was not a serpent. Its outlines were indistinct, but it was taller than a man, and not very bulky. It gave off a glimmer of weird light, like a faint blue flame. Indeed, the eery fire was the only tangible thing about it. It might have been an embodied flame moving with reason and purpose through the blackening woods. (...) The thing glided on without altering its course. Indeed it was only a few instants' fleeting glimpse they had of it - a tall, shadowy thing of misty flame floating through the thickets. Then it was gone, and the forest crouched in breathless stillness (Howard, 1935, Conan Loses His Ax, pars. 82 - 84).

Here once again the demonic creature is described as a chaotic combination of human and animal features. The contrast between the light of a flame and of the surrounding darkness is an image used repeatedly in Beyond the Black River either to suggest the supernatural character of a creature or to introduce the appearance of a supernatural being or threat.

In sword and sorcery fiction the inherent decadence of civilisation is presented through the latter's utter powerlessness in the face of the hostile supernatural. Howard frequently expresses his belief that, due to their lack of contact with the mythological, all members of highly structured societies stand no chance in a struggle with forces from beyond the immediately comprehensible material world. This weakness is manifest in the Aquilonian settlers in Conajohara. Having come back from the forest to the fort, Conan and Balthus have a conversation with the leader of the local garrison, one Vallanus, about the recent, apparently unexplainable deaths. By that time, the supernatural nature of the mortal danger as well as the influence of something mysterious (probably magic) that leads the soldiers to their demise are evident. Vallanus seems unable to fully grasp the essence of the events, and so he starts to reflect on the situation aloud:

What do we know - what does anyone know - of the things that jungle may hide? We have dim rumors of great swamps and rivers, and a forest that stretches on and on over everlasting plains and hills to end at last on the shores of the western ocean. But what things lie between this river and that ocean we dare not even guess. (...) We are wise in our civilized knowledge, but our knowledge extends just so far - to the western bank of that ancient river! Who knows what shapes earthly and unearthly may lurk beyond the dim circle of light our knowledge has cast? Who knows what gods are worshipped under the shadows of that heathen forest, or what devils crawl out of the black ooze of the swamps? Who can be sure that all the inhabitants of that black country are natural? (Howard, 1935, The Wizard of Gwawela, pars. 29-30).

The nature of the threat that Vallanus is facing appears to dawn on the leader of Aquilonian soldiers. However, he admits to his powerlessness as well as his inability to comprehend or even learn about the supernatural. The Aquilonian understands well the essence of his weakness: rather than the outcome of some 
personal shortcoming, it is the result of the limits imposed by the ways his people chose to organise their society. That which lies beyond the Black River lies also beyond their understanding.

Vallanus is also aware of the connection between his conflict with Zogar Sag and the deaths among his personnel. The wizard is known to have claimed to be able to control wild animals (the nature of this ability is to be presented further in the story), and there have been numerous cases of people being attacked and maimed by beasts in the forest in the immediate proximity of the fort. This causes Vallanus to "wonder if [the wizard] is wholly human" (Howard, 1935, The Wizard of Gwawela, par. 30). The events that follow prove that the Aquilonian was correct in questioning the humanity of Zogar Sag.

Balthus, having fallen into a Pictish ambush, finds himself tied to a stake in a village swarming with Pictish warriors who, as it soon turns out, await the appearance of the wizard. The character is blinded by the glare of fires: the Picts appear as "black figures (...) etched against crimson tongues of flame" (Howard, 1935, The beasts of Zogar Sag, par. 1). The image of the contrast of fire and darkness is once again employed for the purpose of presenting the supernatural; unlike in the case of the demon, this time the image is not an integral part of a chaotic creature, but it is used to foreshadow the things to come.

When Zogar Sag appears, the gates in the palisade are opened to the nocturnal forest, and the wizard faces it and utters "a weird inhuman call shuddering out into the night," (Howard, 1935, The beasts of Zogar Sag, par. 16) which is answered by a deeper cry of evidently inhuman quality. As it turns out, the wizard has summoned a beast "like the embodiment of nightmare legend."(Howard, 1935, The beasts of Zogar Sag, par. 18) The reader learns that "Balthus no longer [doubts] the actuality of the shaman's magic", since "only the black arts could establish a domination over that. . . monster" (Howard, 1935, The beasts of Zogar Sag, par. 20) which turns out to be a sabre-toothed tiger, a creature inhabiting tales, legends, and myths of peoples of the Hyborian Age. Then, as "the night [presses] in very black and horrible outside the firelight" and "the fires themselves [glow] lurid as the fires of Hell" (Howard, 1935, The beasts of Zogar Sag, par. 26), Zogar Sag calls forth a giant snake, "the reptile that the ancients called Ghost Snake, the pale, abominable terror that of old glided into huts by night to devour whole families" (Howard, 1935, The beasts of Zogar Sag, par. 30). In this chapter a new aspect of the supernatural character of the powers of Zogar Sag is presented. Not only is the wizard able to control wild animals of the forest, but he is also capable of establishing contact with and dominance over creatures so ancient that the civilised people of Aquilonia believe them to be legendary. It is proven, therefore, that it is possible for the supernatural impersonated by the wizard to freely transcend space and time.

Until this point readers are made to believe that Zogar Sag, despite his power to control supernatural forces, is a Pictish native, and the creatures that are at his service come from the jungle at the Black River. Still, the passages that follow reveal the true nature of the wizard. After saving Balthus from the captivity in the village, Conan and the settler make their escape through the forest, only to find out that they are being followed by a leopard. Apparently, the animal has been 
sent on their trail by Zogar Sag. Here the first mention of a Jhebbal Sag is made, as Conan explains how the wizard controls the creatures of the wild. According to the Conan, Zogar Sag "can't command all the animals, only such as remember Jhebbal Sag" (Howard, 1935, The Children of Jhebbal Sag, par. 27). The nature of Jhebbal Sag is never clearly established in the story; nevertheless, he appears to be a deity, since, as Conan states, "once all living things worshipped him" (Howard, 1935, The Children of Jhebbal Sag, par. 29), which "was long ago, when beasts and men spoke one language" (Howard, 1935, The Children of Jhebbal Sag, par. 29). Conan claims that "the men who remember Jhebbal Sag and the beasts who remember are brothers and speak the same tongue" (Howard, 1935, The Children of Jhebbal Sag, par. 29). Hence, it becomes clear that Zogar Sag's control of the beasts is the result of a mystical connection. The wizard and his creatures worship at the altar of the same god, speak the same ancient language, and, consequently, possess knowledge that transcends the limits of the space and time of the natural world, as well as the understanding of other men.

Conan then proceeds to draw a symbol in the mould. The supernatural power of the sign is presented immediately, as Balthus feels "a crawling of the flesh along his spine" (Howard, 1935, The Children of Jhebbal Sag, par. 39). After seeing the symbol, the leopard bows in an "attitude (...) of awe and adoration" and retreats into the jungle "as if in a sudden panic" (Howard, 1935, The Children of Jhebbal Sag, par. 45). What this scene presents is an example of the structure typical of the sword and sorcery genre. While civilisation is powerless against the supernatural forces, it is the barbarian who is capable of facing them because of the connection that he has with the magical and the mythical, that is, with those aspects of the world that the civilised men of the Hyborian Age perceive as irrational and hence refuse to acknowledge.

The origins of the supernatural beings that invade the natural, material world of the Hyborian Age are described in the passages where Conan finally meets the creature believed to be a swamp demon. Howard again makes use of the imagery of the contrast of fire and darkness, and the chaotic character of the supernatural creature is emphasised by the structure of its body that consists of numerous, misplaced human and animal parts. The demon first comes across as "a weird glow [burning] through the trees" in the night and "a green witch-fire that [moves] with purpose and intent" (Howard, 1935, The devil in the fire, par. 10). When the flames are extinguished, the face and the body of the creature are revealed: the face bears a resemblance to that of Zogar Sag (though with certain deformities) and the body is described as a combination of "a slender torso, covered with snaky scales,... manlike in shape, with man like arms, from the waist upward, below, long cranelike legs [ending] in splay, three-toed feet like those of huge bird" with "the blue fire [fluttering and running] along the monstrous limbs" (Howard, 1935, The devil in the fire, pars. 26). Although the demon takes on a material shape, its structure is chaotic and resembles nothing to be found in nature in the worlds of the Hyborian Age.

When the creature speaks to Conan, it describes its origins. Just like the wizard Zogar Sag, as the reader learns, it is a child of the god Jhebbal Sag. It is, consequently, made evident that the demon and the wizard do not come from the swamps or the jungle beyond the Black River. Although these areas are dangerous and my- 
sterious, they are nevertheless of a material, natural character. The creature and the wizard come from some outside universe, therefore, they are both supernatural in their essence. A number of other deities, beings, objects, and locations is mentioned, such as the black altar of Gullah, the Dark Land, the Mountains of the Dead, the Four Brothers of the Night, the Gulf of Ghosts, the Children of Jhil, old gods residing in the void. Although their exact nature is never divulged, it is certain that they exist in a world of the supernatural. That is why it can be stated that the supernatural elements alter the structure of the presented world of Beyond the Black River completely. Thus, the universe of the Hyborian Age is divided into two spaces: the natural and the supernatural. Elements of the supernatural permeate the natural world, and only the barbarians - uncivilised, yet with a thorough knowledge and understanding of the mythical plane that is utterly incomprehensible to those living in highly organised societies - are not completely powerless when faced with chaotic entities from outside the consistently structured material universe.

\section{CONCLUSION}

In Beyond the Black River Howard coherently uses the contrastive image of fire and darkness to foreshadow and reveal the supernatural nature of certain characters and elements of the world of the short story. Howard connects these images closely with the linear structure of the plot to disclose the supernatural nature and origins of the wizard Zogar Sag and the creatures that serve him. The helplessness of civilised people in the face of the supernatural threat and the barbarian Conan's struggle against the chaotic and the magical described in Howard's Beyond the Black River helped to establish and define the sword and sorcery subgenre.

\section{REFERENCES}

Clute, J. (1997). Fantasy. In: J. Clute \& J. Grant (eds.), The encyclopedia of fantasy. London: Orbit.

Clute, J. (1997). Howard, Robert E(rvin). In: J. Clute \& J. Grant (eds.), The encyclopedia of fantasy. London: Orbit.

Clute, J., Kaveney, R. \& Langford, D. (1997) Sword and Sorcery. In: J. Clute \& J. Grant (eds.), The encyclopedia of fantasy. London: Orbit.

D'Ammassa, D. (2006). Encyclopedia of fantasy and horror fiction. New York, NY: Facts on File

Hinckley, D. (2002). The Conan series. In: F. Kelleghan (ed.), Classics of science fiction and fantasy literature. Pasadena, CA: Salem Press

Hoffman, C. (2004). Conan the existential. In: D. Herron (ed.) The barbaric triumph. Rockville, MD: Wordpress.

Howard, R. E. (1935). Beyond the Black River. Retrieved from http://gutenberg.net.au/ ebooks06/0600741.txt.

Howard, R. E. (1938). The Hyborian Age. Retrieved from http:/ / gutenberg.net.au/ebooks06/0603571.txt.

Jackson, R. (1981). Fantasy. The literature of subversion. London: Methuen.

Parkinson, M.H. (2006). Fantastic. In: P. Childs \& R. Fowler (eds.) The Routledge dictionary of literary terms. Abington: Routledge.

Shovlin, P. (2013). Canaan lies beyond the Black River. In: J. Prida (ed.) Conan meets the academy. Jefferson, NC: McFarland.

Stableford, B. (2005). Historical dictionary of fantasy literature. Lanham, MD: The Scarecrow Press 